\title{
Dilatometric Measurements of Austenitic Stainless Steel as a Function of Temperature
}

\section{Monika Oravcovái ${ }^{\text {, Peter Palček }}{ }^{1}$, Máriusz Król ${ }^{2}$}

${ }^{1}$ University of Žilina, Faculty of Mechanical Engineering, Department of Materials Engineering, Univerzitná 1, 01026 Žilina, Slovakia. E-mail: monika.oravcova@fstroj.uniza.sk, peter.palcek@fstroj.uniza.sk

${ }^{2}$ Institute of Engineering Materials and Biomaterials, Faculty of Mechanical Enginering, Konarskiego 18A Stret, 44-100 Gliwice, Poland. E-mail: mariusz.krol@polsl.pl

Many solid materials are subjected to structural changes, e.g. phase transformations within temperature change. These phase transformations are usually accompanied by a significant change in particular volume. The change in volume of a solid material is measured by the corresponding change in length of a specimen of the material. The experimental method which is based on measurement of volume/ length change during linear heating or cooling is dilatometry. Dilatometry is characterised by the linear thermal expansion coefficient which can be described as the relative length- change divided by the corresponding temperature interval. The basis of the thermal expansion of crystalline material is related with the function between interatomic forces in crystal lattice. This paper investigates the effect of temperature on structural changes within austenitic stainless steel that underwent different heat treatment before the measurement.

Keywords: Austenitic stainless steel, Dilatometry, Temperature dependance, Thermal expansion coefficient

\section{Acknowledgement}

This work has been supported by Scientific Grant Agency of Ministry of Education of Slovak republic VEGA 1/0683/15 and project APVV SK-CZ-2013-0076.

\section{References}

[1] RASHID, M.W.A., GAKIM, M., ROSLI, Z. M., AZAM, M. A. (2012). Formation of Cr23C6 during the sensitization of AISI 304 stainless steel and its effect to pitting corrosion, International Journal of Electrochemical Science, ESG, s. 9465-9477.

[2] LIMA, A. S., NASCIMENTO, A. M., ABREU, H. F. G., LIMA-NETO, P. (2005). Sensitization evaluation of the stainless steel AISI 304L, 316L, 321 and 347, Journal of Materials Science, volume 40, s. 139 - 144.

[3] KHATAK, H.S., RAJ, B. (2002). Corrosion of austenitic stainless steels mechanism, mitigation and monitoring, Woodhead Publishing Limited, Abington Hall, England, s. 117- 130.

[4] ČÍIHAL, V. (1984). Mezikrystalová koroze ocelí a slitin, Praha: SNTL.

[5] McGUIRE, M. F. (2008). Austenitic Stainless Steels, Stainless Steels for Design Engineers, ASM International), s. $69-90$.

[6] PORTER, W. D. (1993). Thermal expansion data on several iron- and nickel-aluminide alloys, Scripta Metallurgica et Materialia, USA.

[7] KANAGARAJ, S., PATTANAYAK, S. (2003). Measurement of the thermal expansion of metal and FRPs, Cryogenics, volume 43, issue 7, s. $399-424$.

[8] ŠVEC, M., MACAJOVÁ, E. (2015). Coefficient Thermal Expansion of Fe3Al and FeAl - type iron aluminides, Manufacturing Technology, volume 13, issue 3, Czech Republic, s. 399 - 404.

[9] MATULA, M., et al. (2001). Intergranular corrosion of AISI 316L steel, Materials Characterization, volume 46, issues 2-3, s. $203-210$.

[10]CHRISTIEN, F., TELLING, M.T.F., KNIGHT, K.S. (2013). A comparison of dilatometry and in-situ neutron diffraction in tracking bulk phase transformations in a martensitic stainless steel, Materials Characterization, volume 82 , s. $50-57$.

[11] DONG-WOO, S., CHANG-SEOK, O., HEUNG, N. H., SUNG-JOON, K. (2007). Dilatometric Analysis of Phase Fraction during Austenite Decomposition into Banded Microstructure in Low-Carbon Steel, Metallurgical \& Materials Transactions, volume 38, issue 12, s. $2963-2973$. 